\title{
Total Physical Response and Direct Method in Students' Vocabulary Mastery Learning
}

\author{
Choiril Anwar \& Diah Fitriani \\ Sultan Agung Islamic University, Semarang
}

\begin{abstract}
The objective of this study was to test which one of the two methods (TPR and DM) were more effective to improve the students' vocabulary mastery. The population of this study was all of the fifth graders of SD Islam Sultan Agung 4 Semarang in the academic year of $2015 / 2016$. The instrument of the study was vocabulary test consisted of multiple choice items and matching items. Before treatment was given, pre-test was conducted to both groups. Meanwhile, post-test was conducted after the treatment had finished. The result showed that the mean of the experimental and control group in pre-test were 64.35 and 65.30 , respectively. After being given the treatment, post-test was conducted in both groups. The t-test calculation showed that there was a significant difference. So, Total Physical Response method was more effective than Direct Method in learning English Vocabulary to the fifth graders of Elementary Students.
\end{abstract}

Keywords: Total Physical Response, Direct method, and Vocabulary

\begin{abstract}
Abstrak
Tujuan dari penelitian ini adalah untuk menguji mana dari dua metode (TPR dan DM) yang lebih efektif untuk meningkatkan kemampuan penguasaan kosa kata siswa. Subjek penelitiannya adalah semua siswa kelas 5 SD Islam Sultan Agung 4 Semarang Tahun Ajaran 20I5/2016. Instrumen penelitiannya berupa tes kosa kata yang terdiri dari pilihan ganda dan menjodohkan. Sebelum perlakuan diberikan, kedua grup diberikan pre-test. Sedangkan post-test diberikan setelah perlakuan selesai. Hasilnya menunjukkan bahwa rata-rata grup eksperimen dan kontrol berturut-turut adalah 64.35 dan 65.30. Setelah diberikan perlakuan, kedua grup diberikan post-test. Nilai rata-rata untuk kedua grup berturut-turut adalah 78.65 dan 7I.70. Perhitungan t-test menunjukkan adanya perbedaan yang mencolok. Jadi, metode Total Physical Response lebih efektif daripada Direct Method dalam pembelajaran kosa kata Bahasa Inggris pada siswa kelas lima sekolah dasar.
\end{abstract}

Kata Kunci: Total Physical Response, Direct method, and Vocabulary

Coressponding author

Email: choirilanwar@unissula.ac.id, diahfitriani2@gmail.com 


\section{Introduction}

Primary school students who learn English have many difficulties, especially in pronouncing and understanding the meaning of the words. So that, in learning English, vocabulary has an important role especially for young learners. According to Cameron (2001: 72), building up a useful vocabulary is central to the learning of a foreign language at primary level. It means, young learners have to learn vocabulary first before they can comprehend other elements of language such as grammar and writing.

In this case, the writers used Total Physical Response (TPR) method compared with Direct Method (DM) in teaching vocabulary. Direct Method is such a method of teaching and learning, in which the English teacher will teach English vocabulary by using direct things or real object, bags of oral interaction, spontaneous language use, there is not any translation between first and second language as well (Brown, 2001: 21). Whereas, Total Physical Response is a method of teaching which is able to combine the English vocabulary meaning with actions, pictures, and objects (Brown, 2001: 29). It is not only a useful way to teach an accurate meaning of each English vocabulary to the pupils, but it can also help them to recall the meaning of English vocabulary. Therefore, the TPR method or DM are efficient and can be applied in teaching English vocabulary. In addition, those two methods have not been taught by the teacher in SD Islam Sultan Agung 4 Semarang.

There were many reasons that could be presented by the writers in choosing this topic entitled. First, English is one of the most difficult subjects for Indonesian students. Second, the writers believed that TPR or DM can be developed as an interesting teaching method in vocabulary. The characters of TPR or DM were appropriate with the young learners' character in the way of learning. Third, by applying TPR or DM the students of elementary school were expected to be more interested and enjoy in studying English. Fourth, the two methods, Total Physical Response and Direct Method, have not been taught intensively by the teachers in SD Islam Sultan Agung 4 Semarang.

\section{Teaching English to Young Learners}

Dickinson as quoted by Ghani and Ghous (2014: 4) defines young learners as learners between five and twelve years of age. Li, Wu and Hou cited in Ghani and Ghous (2014: 4) also defines young learners as children from the first formal schooling, five or six years old to eleven or twelve years of age. It means that young learners are students who are studying English in elementary school whose ages 6-12 and they study English as a foreign language. Young learners have different motivation from the students in higher level like Junior High School, Senior High School and University. Therefore, teachers need some innovations in teaching English to young learners and one of the ways is using Total Physical Response 
method or Direct Method.

Vocabulary

A foreign language's learners will speak fluently and accurately, write easily, or understand what the learner reads or hears if they have enough vocabulary and have the capability of using it accurately.

Obviously, vocabulary is very important in learning a language, especially in learning English, because the English vocabulary is extremely large and varies as well. According to El-Koumy (2004: 40), vocabulary is an essential component of language and we would be totally mistaken if we ignore teaching it. Wilkins (1972: 111) wrote that “... while without grammar very little can be conveyed, without vocabulary nothing can be conveyed”.

\section{Total Physical Response}

Richards and Rodgers (2001: 87) claimed that TPR is a language teaching method built around the coordination of speech and action; it attempts to teach language through physical (motor) activity". From the statement, it can be said that, the basic idea behind Total Physical Response Method is that students hear something from the teacher and then physical response to it and usually the teacher as a model for the students. That is in Total Physical Response (TPR), a beginning or more advanced students learn to comprehend things said by a teacher.

\section{Direct Method}

According to Richards and Rodgers (2001: 11), Sauveur and other believers in the Natural Method/Direct Method argue that foreign language can be taught without any translation or the use of the learners' native language if the meaning is conveyed directly through demonstration and action. And at the beginning of the twentieth the direct method had a definite pattern and the term "Direct Method" was established. The Direct Method was finally developed in different directions in different countries. Direct Method truly contributed a great deal of improvement in teaching another language in the world.

\section{Research Method}

Research project needs a research design in order to make the research more objective and accurate. The quantitative approach was used in this study, Kothari (2004: 27) states, "Quantitative research is based on measurement of quantity or amount. The research design of this study was an experimental research. According to Airasian (2000: 367), experimental study is the only type of study that can test hypotheses to establish cause-and-effect relationships. It represents the strongest chain of reasoning about the links between variables. 
"The different conditions under which experimental and control groups are usually referred to as 'treatment' (Kothari, 2004: 35)". According to Fraenkel \& Wallen (2009: 262), “control group" receives no treatment or the comparison group may receive a different treatment.

Population and sample are very essential means of data collection in every research. In this study, the writers took all of fifth-grade students of SD Islam Sultan Agung 4 in the academic year of $2015 / 2016$ as the population. While sample is the process of selecting a number of individuals for a study in such a way that they represent the larger group from which they are selected (Airasian, 2000: 121). In this study, the writers used purposive sampling. This a kind of sampling is conducted when the researchers select a sample based on their experience or knowledge of the group.

Table 1. Sample of the Study

\begin{tabular}{|l|l|}
\hline \multicolumn{2}{|c|}{ SAMPLE } \\
Experimental & Control \\
Group & Group \\
$\mathrm{V} \longrightarrow \mathrm{A}$ & $\mathrm{V} \longrightarrow \mathrm{B}$ \\
\hline \multicolumn{2}{|c|}{ Total Sample $=53$} \\
\hline
\end{tabular}

The writers used a selection test items which were multiple choice item and matching item to get the data. This test was chosen because it was effective; practical; and objective. In this test, the writers gave 1 point for the correct answer and 0 point for the wrong answer. A multiple-choice item consists of a stem, which presents the problem or question to the student, and a set of options, or choices, from which the student selects an answer. Matching items consist of a column of premises, a column of responses, and directions for matching the two (Airasian \& Russel, 2008: 146-147).

Validity and Reliability

This study used content and construct validity. For the content validity, because there is no statistical means, it was determined by the expert judgment. To know the construct validity of the test, the writers gave 35 items that were tested in the form of multiple choices and matching items as the type of test.

According to Airasian (2011: 169), reliability is degree to which a test consistently measures whatever it measures. Reliability is expressed numerically, usually as a coefficient indicates high reliability. The writers measured to find out the reliability using Cronbach Alpha Formula in SPSS with following ways; input Data-Analyze-Scale-ReliabilityAlpha. 
Data Collection

The writers chose the population of the study that was the fifth graders of SD Islam Sultan Agung 4 Semarang in the academic year of 2015/2016. The writers conducted the study in these steps; Try-Out, Pre test, Giving Treatment, Post test. The writers collected the post test students' answer, then scored them. The last, the writers analyzed the data.

Data Analysis

After collecting the data, the writers analyzed them. After doing the scoring of the test, the writers processed the result of the students' test. The test consisted of 30 questions. In scoring, each item got 1 point for the correct answer and 0 point for the wrong answer. For scoring, the writers used the following formula.

$$
\mathrm{TS}=\frac{\mathrm{SS}}{\mathrm{MS}} \times 100 \%
$$

Note: $\mathrm{TS}=$ Total Score

SS $=$ Students' Score

MS = Maximum Score

(Azhar, 1993: 124)

Knowing the level of students' vocabulary achievement was strongly important, so that after conducting the test, it should be classified into some groups. According to Harris (1969: 134), these following are the level of achievement.

Table 2. The Level of Achievement

\begin{tabular}{|cc|}
\hline Criteria of Score & Level \\
\hline $91-100$ & Excellent \\
$81-90$ & Very good \\
$71-80$ & Good \\
$61-70$ & Fair \\
$51-60$ & Poor \\
Less than 50 & Very poor \\
\hline
\end{tabular}

(Harris, 1969: 134)

In collecting the data to complete the study, the writers collected the data and analyzed them in the following steps:

First, the writers collected the data. The computation result of pretest and posttest was in a ratio scale. Second, after doing the scoring of the test, the writers processed the data statistically to know the homogeneity and normality. The writers analyzed the multivariate normality by using one-sample Kolmogorov-Smirnov test and for the homogeneity test the writers processed the data by using Independent sample test. Third, after getting the result, the writers continued to determine the hypothesis by using independent sample t-Test Formula. 
The writers used SPSS for Windows System 21.0 version to determine the hypothesis, standard of normality, and the homogeneity.

The standard of normality is 0.05 . Ghozali (2011:34) stated that the data distribution is said as normal if sig (2-tailed) $>0.05$. Otherwise, if sig ( 2 -tailed) $<0.05$, the distribution is not normal. Whereas, to calculate the homogeneity of the data, the writers used Levene test. According to Hartono (2008: 170), the probability of this test is:

$\mathrm{H}_{0}$ : if sig (2-tailed) $>0.05$, the data are homogenous.

$\mathrm{H}_{1}$ : if $\operatorname{sig}(2$-tailed $)<0.05$, the data are heterogenous.

In this study, there were some criteria of hypothesis:

a). If $\mathrm{t}$-value $>\mathrm{t}$-table and sig. $<0.05$, it means that $\mathrm{H}_{1}$ is accepted and $\mathrm{Ho}$ is rejected.

b). If $\mathrm{t}$-value $<\mathrm{t}$-table and sig. $>0.05$, it means that $\mathrm{H}_{1}$ is rejected and Ho is accepted.

\section{Finding and Discussion}

\section{Validity}

In this study, the writers used content and construct validity. For the content validity, because there is no statistical means, it was determined by the expert judgment. The writers consulted the content of the test with the real teacher. For the construct validity, the writers used Pearson Product Moment Formula. Before the writers gave pre-test to the students, the writers gave try out first to the students on another school. The function of giving try out was to know the validity and reliability of the test. The test consisted of 35 questions.

The data was valid if the score of $r$-value in the pearson correlation is more than $r$ table result, $r$ table at the level of significant $5 \%(p=0.05)$ could be searched based on the number of respondents or $\mathrm{N}$. Therefore, for $\mathrm{N}=22$, then the degree of freedom was $\mathrm{N}-2=22-2=$ 20 , therefore $\mathrm{r}$ table value for $\mathrm{df}=20$ and $\mathrm{p}=0.05$ was 0.422 . The result showed that there were 31 questions had $\mathrm{r}$ value upper than 0.422 , and 4 questions had $\mathrm{r}$ value lower than 0.422 . Because of the writers needed 30 questions, thus one question which was valid did not used in the test. The result was shown in the following table.

Table 3.

The Result of Validity

\begin{tabular}{|ll|}
\hline Item & Question Number \\
\hline Valid questions & $1,2,3,5,6,7,8,9,10,11,12,13,15,16,17$, \\
& $18,19,20,21,22,23,24,25,27,28,29,30$, \\
& $31,33,34,35$ \\
\hline Invalid questions & $4,14,26,32$ \\
& \\
\hline
\end{tabular}




\section{Reliability}

After the writers got the validity of the test, the writers continued to calculate the reliability of the test by using Cronbach Alpha formula in SPSS for Windows Release version 21.0. It was found that the reliability of the test was 0.907. According to Ghozali (2011: 42), it can be said that the instrument is reliable if Cronbach's Alpha $>0.60$. Therefore, from the result of reliability above, it can be concluded that the instrument was reliable, because 0.907 was higher than 0.60 . The result of reliability can be seen below.

Table 4.

The Result of Reliability Test

\begin{tabular}{|cc|}
\hline Cronbach's Alpha & N of Items \\
\hline .907 & 31 \\
\hline
\end{tabular}

\section{Pre-test Analysis}

The pre-test of both experimental group and control group were conducted on August, $7^{\text {th }} 2015$. There were 53 students who participated in this activity. They were experimental group consisted of 26 students and control group consisted of 27 students. The purpose of this activity was to know the students' ability in mastering English vocabulary before the treatments were given to them. The vocabulary test consisted of 30 questions comprised 22 multiple choice items with four options of each item and 8 matching items.

The pre-test was given to the control and the experimental groups, the score of pretest both experimental and control can be seen in the appendix 10 and 11. After getting the result, the writers grouped the score of both groups experimental and control into the following criteria in the table 5.

Table 5.

The result of the pre-tests' level ability of Experimental and Control Group

\begin{tabular}{|clc|}
\hline & Level & Number of students \\
\hline Experimental & Excellent & - \\
& Very Good & 3 \\
& Good & 5 \\
& Fair & 9 \\
& Poor & 4 \\
& Very poor & 5 \\
\hline
\end{tabular}




\begin{tabular}{|lll|}
\hline Control & Excellent & - \\
& Very Good & 3 \\
& Good & 6 \\
& Fair & 9 \\
& Poor & 4 \\
& Very Poor & 5 \\
\hline
\end{tabular}

From the table 5, it is derived that in experimental group there were 3 students in the level Very Good, 5 students in the level Good, 9 students in the level Fair, 4 stduents in the level Poor and 5 students in the level Very Poor. Whereas, In control group there were 3 students in the level Very Good, 6 students in the level Good, 9 students in the level Fair, 4 students in the level Poor and 5 students in the level Very Poor.

Very Good if the student got the score 81-90. Good if the students got the score 71-80. Fair if the student got the score 61-70. Poor if the student got the score 51-60. Very Poor if the students got the score less than 50 .

The last, the writers checked the normality and homogeneity of the data by using SPSS for Windows Version 21.0. To know the standard of normality both groups experimental and control, the writers used One-Sample Kolmogorov Smirnov test. The result can be seen in the table below.

Table 6.

The Result of normality both Control and Experimental

One-Sample Kolmogorov-Smirnov Test

\begin{tabular}{|llrr|}
\hline & & Exp. & Control \\
\hline $\mathrm{N}$ & & 26 & 27 \\
Normal Parameters ${ }^{\mathrm{a}, \mathrm{b}}$ & Mean & 64.35 & 65.30 \\
& Std. Deviation & 15.391 & 13.234 \\
Most Extreme & Absolute & .145 & .144 \\
Differences & Positive & .078 & .095 \\
Kolmogorov-Smirnov Z & Negative & -.145 & -.144 \\
Asymp. Sig. (2-tailed) & & .741 & .747 \\
\end{tabular}

Test distribution is Normal.

The data analysis of standard normality above shows that the total students $(\mathrm{N})$ of experimental was 26 , the mean was 64.35 and the standard deviation was 15.391 . Whereas, the total students $(\mathrm{N})$ of control was 27 , the mean was 65.30 and the standard deviation was 13.234. The distribution both group experimental and control were normal, because the data of experimental group showed that the sig. $(2$-tailed $)=0.642(>0.05)$ and the data of control group showed that the sig. $(2$-tailed $)=0.632(>0.05)$. 
After getting the normality, to know the homogeneity of the test, the writers used independent samples test in SPSS for Windows Release version 21.0. The result of the homogeneity can be seen in the following table.

Table 7.

Independent Samples Test

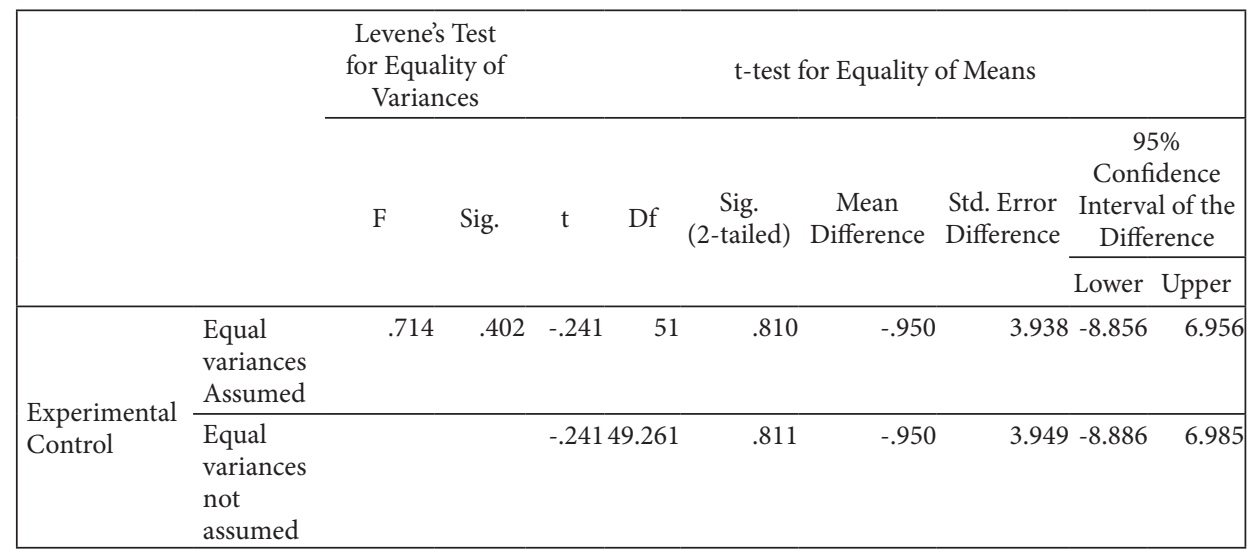

Sig. (2-tailed) $\leq 0.05=$ Significance difference

Sig. $(2$-tailed $) \geq 0.05=$ No significance difference

The table 7 shows that the total number of subjects $(\mathrm{N})$ in this study for both groups experimental and control was 53 with the degree of freedom $(\mathrm{df})=\mathrm{N}-2=51$. The result of independent sample t-test for pre-test showed that $\mathrm{t}$-value derived was -0.241 and $\mathrm{t}$ table was 2.007 , thus $t$-value was lower than $\mathrm{t}$-table $(-0.241<2.007)$.

Furthermore, the independent sample t-test showed that sig. (2-tailed) was $0.810 \geq$ 0.05 and $0.811 \geq 0.05$ for experimental and control group respectively. So that, from the table above, the writers concluded that there was no significance difference between experimental and control group in pre-test, since Sig.(2-tailed) $\geq 0.05$. It means that the students of experimental and control group had the same ability of English Vocabulary before they were given treatment by the writers.

Whereas the treatment was conducted on August $11^{\text {th }}, 13^{\text {th }}, 18^{\text {th }}, 20^{\text {th }} 2015$ for class VA as the experimental group. This class consisted of 26 students. The students were taught by using Total Physical Response method in teaching English vocabulary which was taught in four meetings. Each meeting had 70 minutes.

The first meeting, the topic was parts of body. First, teacher gave pictures and asked to the students what parts of body are. Then, teacher explained parts of body by using some videos. After that, teacher demonstrated some physical movements, such as "Head, shoulder, knees and toes" and followed by the students. Next, the students were asked to do it by themselves while the teacher gave the commands. Teacher asked to the students who already prepared to give command to be a reader and the other students were performers. They took 
a turn to be performers and to be a reader. Then, teacher wrote the series of actions and did oral repetitions. Last, the students asked to do partner activities to answer some questions from the teacher.

The second meeting, the topic was occupation. First, teacher asked to the students what kind of occupation they already known. After that, some students were asked to be volunteers to demonstrate their parents' job. Next, the class acted out what they want to be in the future. Then, teacher wrote the material on the whiteboard, it was about how to write our job. After the students understood, they were asked to write sentences about "Occupation", such as, "My mother is a teacher". Then, the teacher gave explanation to the students once more to make them understood before they were given a quiz. Last, teacher asked to students to do a quiz based on the material that was given by the teacher.

The third meeting, the topic was hobbies. First, teacher asked to the students, what their hobbies are. After that, teacher introduced the material to the students and asked the students became volunteers. Then, they were asked to observe some pictures and listen to what the teacher said and repeat it. After that, they were asked to describe their hobbies and took a turn with their friends to become a reader, such as "she likes dancing" and other became a performer. Next, teacher gave explanation to the students how to ask people's hobbies. Last, the students were asked to answer some evaluation questions that were given by the teacher.

The fourth meeting, the topic was daily activities. First, teacher asked to the students what daily activities' vocabulary they already known. After that, teacher introduced the material through pictures. Then, teacher asked some students became volunteers and gave response to what teacher said. Next, students who already prepared are asked to give commands to the students and they took a turn as a reader and performer. Then, teacher wrote on the whiteboard how to write an imperative sentence and simple present tense in "daily activity" and followed by the students. Last, teacher gave some evaluation questions and the students answered it.

\section{Post-test Analysis}

The post-test of both experimental and control group was conducted on August $22^{\text {nd }}$ 2015. This test was given after the writers gave treatment by using Total Physical Response to the experimental group and Direct Method to the control group. The post-test was conducted in order to know the ability of the students after they got treatment in two different methods. There were 53 students; they were divided into two groups 26 students of experimental group and 27 students of control group. This test was the same as the pre-test. The writers gave students vocabulary test consisted of 30 questions comprised 22 multiple choice items with four options in each item and 8 matching items. 
After getting the result, the writers grouped the score of both groups experimental and control into the following criteria in the table below.

Table 8.

The result of the post-tests' level ability of Experimental and Control Group

\begin{tabular}{|llc|}
\hline & Level & Number of students \\
\hline Experimental & Excellent & 3 \\
& Very Good & 10 \\
& Good & 6 \\
& Fair & 5 \\
& Poor & - \\
& Very poor & 2 \\
\hline Control & Excellent & 1 \\
& Very Good & 3 \\
& Good & 8 \\
& Fair & 12 \\
& Poor & 2 \\
& Very Poor & 1 \\
\hline
\end{tabular}

From the table 8 , it is derived that in experimental group there were 3 students in the level Excellent, 10 students in the level Very Good, 6 students in the level Good, 5 students in the level Fair and 2 students in the level Very Poor. Whereas, In control group there were 1 student in the level Excellent, 3 students in the level Very Good, 8 students in the level Good, 12 students in the level Fair, 2 students in the level Poor and 1 student in the level Very Poor.

Excellent if the student got the score 91-100. Very Good if the student got the score 8190. Good if the students got the score 71-80. Fair if the student got the score 61-70. Poor if the student got the score 51-60. Very Poor if the students got the score less than 50.

Then, after the writers tabulated the students' score of post test, the writers analyzed the normality and homogeneity of the data by using SPSS for Windows Release version 21.0. The writers used One-Sample Kolmogorov Smirnov test to know the normality of the data. The result is shown in the table below.

Table 9.

The Result of Normality both Control and Experimental

\begin{tabular}{|llrr|}
\hline & & Experimental & \multicolumn{1}{c|}{ Control } \\
\hline N & & 26 & 27 \\
& Mean & 78.65 & 71.70 \\
& Std. Deviation & 13.894 & 10.163 \\
Most Extreme Differences & Absolute & .154 & .137 \\
& Positive & .101 & .122 \\
Kolmogorov-Smirnov Z & Negative & -.154 & -.137 \\
Asymp. Sig. (2-tailed) & & .785 & .710 \\
\end{tabular}


a. Test distribution is Normal.

The data analysis of standard normality above shows that the total students $(\mathrm{N})$ of experimental was 26 , the mean was 78.65 and the standard deviation was 13.894 . Whereas, the total students $(\mathrm{N})$ of control was 27 , the mean was 71.70 and the standard deviation was 10.163. The distribution both group experimental and control was normal, because the data of experimental group showed that the sig. (2-tailed) $=0.569>0.05$ and the data of control group showed that the sig. $(2$-tailed $)=0.695>0.05$.

After getting the different treatment, based on the data above, the mean of both groups experimental and control were different. For experimental and control groups respectively, the mean was 78.65 and 71.70. Then, for showing the homogeneity of the data, the writers used group statistic and independent sample test and it can be seen in the table 10 .

Table 10

Group Statistics

\begin{tabular}{|llrrrr|}
\hline & Group & N & Mean & $\begin{array}{c}\text { Std. } \\
\text { Deviation }\end{array}$ & Std. Error Mean \\
\hline $\begin{array}{l}\text { Experimental } \\
\text { Control }\end{array}$ & 1 & 26 & 78.65 & 13.894 & 2.725 \\
\cline { 2 - 6 } & 2 & 27 & 71.70 & 10.163 & 1.956 \\
\hline
\end{tabular}

The mean difference between experimental group and control group was 6.95. Hence, it showed that both groups control and experimental were non-homogeneous. Then, for analyzing the hypothesis of the study, the writers used Independent Sample Test in the following table.

Table 11.

Independent Samples Test

\begin{tabular}{|c|c|c|c|c|c|c|c|c|c|c|}
\hline & & \multicolumn{2}{|c|}{$\begin{array}{c}\text { Levene's Test } \\
\text { for Equality of } \\
\text { Variances } \\
\end{array}$} & \multicolumn{7}{|c|}{ t-test for Equality of Means } \\
\hline & & \multirow[t]{2}{*}{$\mathrm{F}$} & \multirow[t]{2}{*}{ Sig. } & \multirow[t]{2}{*}{$\mathrm{T}$} & \multirow[t]{2}{*}{$\mathrm{df}$} & \multirow[t]{2}{*}{$\begin{array}{c}\text { Sig. } \\
\text { (2-tailed) }\end{array}$} & \multirow[t]{2}{*}{$\begin{array}{c}\text { Mean } \\
\text { Difference }\end{array}$} & \multirow[t]{2}{*}{$\begin{array}{l}\text { Std. Error } \\
\text { Difference }\end{array}$} & \multicolumn{2}{|c|}{$\begin{array}{l}\text { 95\% Confidence } \\
\text { Interval of the } \\
\text { Difference }\end{array}$} \\
\hline & & & & & & & & & Lower & Upper \\
\hline \multirow[b]{2}{*}{$\begin{array}{l}\text { Experimental } \\
\text { Control }\end{array}$} & $\begin{array}{l}\text { Equal } \\
\text { variances } \\
\text { assumed } \\
\end{array}$ & 3.344 & .073 & 2.084 & 51 & .042 & 6.950 & 3.335 & .256 & 13.645 \\
\hline & $\begin{array}{l}\text { Equal } \\
\text { variances } \\
\text { not } \\
\text { assumed }\end{array}$ & & & 2.072 & 45.728 & .044 & 6.950 & 3.354 & .198 & 13.703 \\
\hline
\end{tabular}

Sig. $(2$-tailed $) \leq 0.05=$ Significant difference

Sig.(2-tailed) $\geq 0.05=$ No significant difference

The result of independent sample t-test for post-test showed that $\mathrm{t}$-value was obtained 2.084 Sig. (2-tailed) was obtained 0.042 and 0.044 , and for the $95 \%$ Confidence Interval of the Difference was obtained 0.256 for the lower interval and 13.645 for the upper interval. 
The total number of subjects $(\mathrm{N})$ in this study for both groups experimental and control was 53. Since the degree of freedom for both of groups were $53(\mathrm{df}=53)$, that was $\mathrm{NX}+\mathrm{NY}-2=$ 51. The writers found that $t$ value was 2.084 and $t$ table was 2.007 , so $t$-value was higher than t-table $(2.084>2.007)$.

In addition, the Independent Sample T-test showed that sig (2-tailed) was $0.042<0.05$. It meant that $\mathrm{H}_{0}$ was declined and $\mathrm{H}_{1}$ was accepted. The sig of $\mathrm{t}$-test for equality of means $0.042<0.05$, it meant that the $\mathrm{H}_{0}$ was rejected. It can be said that there was a significant difference on students' vocabulary achievement between students who were taught by using Total Physical Response and who were taught by using Direct Method in post-test. It meant that the mean of experimental group was higher than the mean of control group.

The main objective of this study was to know the students' achievement in learning vocabulary after being taught by using Total Physical Response and taught by using Direct Method of fifth graders of SD Islam Sultan Agung 4 Semarang in the academic year of 2015/2016. For the first time, to know the students' ability before they were given treatment, the writers held pre-test. In the pre-test, the mean scores of the experimental group and the control group were 64.35 and 65.30 respectively. From the result of pre-test it could be said that the ability of two groups was relatively the same. After they received the different treatment the average score of the experimental group was higher than that of the control group.

The experimental group got 78.65 and the control group got 71.70. From the pre-test scores, it could be concluded that the average score of the experimental group in post-test was better than the score of control group. In pre-test, the mean score of experimental group was 64.35 , but after being taught by using TPR, in post-test the mean score of experimental had significantly increase, it was 78.65 .

Meanwhile, the mean score of control group in pre-test was 65.30 , but after being taught by using DM, in post-test the mean score of control group increased to 71.70. It meant that teaching English Vocabulary to elementary students using Total Physical Response method was more effective than teaching it using Direct Method. Students in both groups of experimental and control had improvement in their English Vocabulary, but students in experimental group who were taught by using TPR were more interested, enthusiastic, pleasant and active. The students paid more attention in the teaching learning process which used method that appropriate to them.

An appropriate method could stimulate them to participate in learning English. By using TPR, the students could reduce their anxiety in learning foreign language; they used their physical movement to understand the meaning of the language. After giving treatment, students' vocabulary achievement of SD Islam Sultan Agung 4 Semarang improved. They could enjoy the teaching learning process and they were motivated to learn more about English vocabulary. 


\section{Conclusions}

The use of Total Physical Response method could increase students' vocabulary achievement. It could be seen in the pre-test, the mean score was 64.35 and after got the treatment, in the post-test the mean score was 78.65. They could also produce more vocabulary, before they got the treatments, the students did not know how to respond the command from the teacher and after being taught by using Total Physical Response, the students were able to respond that command, give command and able to understand the language. The use of Direct Method could increase students' vocabulary achievement. It could be seen in the pretest the mean score was 65.30 and after got the treatment, in the post-test the mean score was 71.70. They could also produce more vocabulary; before they got treatment the students did not know how to respond the question from the teacher, correctly and after being taught by using Direct Method, the students were able to answer that question correctly.

There was a significant difference of the students' vocabulary achievement in learning vocabulary between students who were taught by using Total Physical Response and those who were taught by using Direct Method to the students of SD Islam Sultan Agung 4 Semarang in the academic year of 2015/2016. The writers found that $t$ value was 2.084 and $t$ table was 2.007, so t-value was higher than t-table $(2.084>2.007)$. In addition, the Independent Sample T-test showed that sig $\left(2\right.$-tailed) was $0.042<0.05$. It meant that $\mathrm{H}_{0}$ was declined and $\mathrm{H}_{1}$ was accepted.

There are some suggestions to consider in this study. They are as the following: (1) Teachers should realize that learning a foreign language needs an appropriate method, such as Total Physical Response it is an appropriate way to improve elementary students' English vocabulary achievement; (2) In teaching English, teachers need to give motivation and need to be more creative in order to make the students more enthusiastic, cozy, active and interested in learning English; (3) Students should not be worried to learn English. They should participate, practice more and enjoy learning English. It will reduce the students' anxiety in learning English; and at last (4), The students should also apply what they have received in learning English in their daily life whether in oral or written ways. 


\section{References}

Airasian, P. W. and L. R. Gay. (2000). Education Research: Competence for Analysis and Application (6 $6^{\text {th }}$ Ed.). New Jersey: Merrill Prentice Hall. and Russel, M. K. (2008). Classroom Assessment. (6 ${ }^{\text {th }}$ Ed.) Boston: McGrawHill Publishing Company. , L. R. Gay., and G. E. Mills. (2011). Educational Research: Competencies for Analysis and Applications (10 ${ }^{\text {th }}$ Ed.). New Jersey: Pearson

Education, Inc.

Arikunto, Suharsimi. (2006). Prosedur Penelitian Suatu Pendekatan Praktik. Jakarta: PT. Rineka Cipta.

Azhar, Lalu M. (1993). Proses Belajar Mengajar Pola C.B.S.A. Surabaya: Usaha Nasional.

Brown, H. D. (2001). Teaching by Principles: and Interactive Approach to Language Pedagogy. $\left(2^{\text {nd }}\right.$ Ed.). San Francisco State University: Longman.

Cameron, Lynne. (2001). Teaching Languages to Young Learners. Cambridge:

Cambridge University Press.

El-Koumy, Abdel S. A. K. (2004). Teaching and Learning English as A Foreign Language: A Comprehensive Approach. USA: Educational Resources Information Center (ERIC).

Fraenkel, Jack R. And Norman E. Wallen. (2009). How to Design and Evaluate

Research in Education. ( $7^{\text {th }}$ Ed.). New York: McGraw-Hill.

Ghani and Ghous. (2014). The Effectiveness of Total Physical Response (TPR) Approach in Helping Slow Young Learners with Low Achievement Acquire English as A Second Language. International Journal of Research in Social Science. Vol. 4, No.6, 2014. Retrieved on May 185, 2015 from the World Wide Web: www. Ijsk.org/ijrss

Ghozali, I. (2011). Aplikasi Multivariate: Dengan program SPSS. Semarang: Diponegoro University.

Harris, D. P. (1969). Testing English as a second Language. USA: McGraw-Hill, Inc.

Hartono. (2008). SPSS 16.0 Analisis Data Statistika dan Penelitian. Yogyakarka: Pustaka Belajar.

Kothari, C.R. (2004). Research Methodology: Methods and Techniques. (2 ${ }^{\text {nd }}$ revised Ed.). New Delhi: New age International Publishers.

Richards, J. C. and Rodgers, T. S. (2001). Approaches and Methods in Language Teaching. Cambridge: Cambridge University Press.

Wilkins, David A. (1972). Linguistics in Language Teaching. Cambridge, MA: MIT Press. 